\title{
Relationship between Teaching Context and Teachers' Orientations to Science Teaching
}

\author{
Lydia Mavuru ${ }^{1 *}$, Umesh Ramnarain ${ }^{1}$ \\ ${ }^{1}$ University of Johannesburg, Gauteng, SOUTH AFRICA
}

Received 25 January 2018 • Revised 16 April 2018 • Accepted 1 May 2018

\begin{abstract}
The social context available to science teachers is known to influence their classroom practices or pedagogical orientation. This study investigated how social context influences pedagogical orientations at three township schools in South Africa. The study employed a qualitative case-study design involving three Grade 9 Natural Sciences teachers. Data collection involved pre-lesson interviews; lesson observations using the Reformed Teaching Observation Protocol (RTOP); post-lesson interviews; and analysis of documents. Data were analysed using a constant comparative method. Findings revealed that learners' socio-cultural practices, experiences and beliefs influenced teachers' pedagogical orientations in two important ways. Firstly, their teaching became more process- and activity-driven. Secondly, teachers' views about the goals of science teaching changed. Rather than a focus purely on curriculum coverage and exam preparation, building learner confidence, stimulating appreciation for the relevance of science, and motivating learners also became important. Implications drawn for in-service and pre-service teacher development programmes are discussed.
\end{abstract}

Keywords: pedagogical orientations, teaching and learning context, natural sciences

\section{INTRODUCTION}

This paper reports on how teachers' knowledge of their teaching context influences their pedagogical orientations to science teaching. It is part of a larger study which explored the role contextual knowledge plays in the pedagogical content knowledge (PCK) of selected Grade 9 Natural Sciences (NS) teachers in township schools. Contextual knowledge referred to learners' Indigenous Knowledge Systems (IKS), which Odora-Hoppers (2001) defined as being characterised by its 'embeddedness in the cultural web and history of a people including their civilization and forms the backbone of social, economic and technological identity' (p. 74). As such, learners' IKS is expressed through their socio-cultural practices, experiences and beliefs. 'Township school' refers to an institution of learning which is located in the then underdeveloped urban areas allocated for Blacks during the era of apartheid in South Africa. It should be noted that in spite of the integration process that took place in the education sector after achieving democracy in 1994, schools which were previously reserved for a particular race still remain highly populated by that group (Chisholm \& Sujee, 2006). As a result, township schools are populated with Black learners and are characterised by poor socio-economic status which Bush and Heystek (2003) condemned as perpetuating racial segregation. Because most parents are not gainfully employed or unemployed, they contribute minimally through school fees; hence, most schools are generally under-resourced and overcrowded (Onwu \& Stoffels, 2005). In some cases, learners are constantly fearful of crime and violence (Hammett, 2008; Prinsloo, 2005).

Research has indicated that science teachers' practices are influenced by factors such as the social context of their work environment (Little, 2003), which is herein referred to as teachers' knowledge of the teaching context; their subject matter knowledge (Abell, 2007); general pedagogical knowledge (Çimer, 2007); their beliefs about teaching or orientations (Jones \& Carter, 2007); and their PCK (Abell, 2007). In the study the relationship and interaction between teachers' knowledge of their teaching context and teachers' beliefs about the goals and purposes of science teaching and learning (teachers' orientations) was explored. The current paper does not focus

(C) 2018 by the authors; licensee Modestum Ltd., UK. This article is an open access article distributed under the terms and conditions of the Creative Commons Attribution License (http://creativecommons.org/licenses/by/4.0/). \lydiam@uj.ac.za (*Correspondence) $\bigotimes$ uramnarain@uj.ac.za 


\section{Contribution of this paper to the literature}

- In a science-classroom situation, science teachers face daunting challenges which: firstly, include recognising and understanding diverse learners' socio-cultural backgrounds in the classroom; and, secondly, finding the most suitable ways to manage these differences for effective engagement of learners with science concepts.

- Information on the role of context in shaping the pedagogical orientations of teachers towards science teaching informs teachers about appropriate pedagogical approaches in science teaching by presenting strong descriptions of dynamic features of teaching in socio-culturally diverse environments.

- In this way, the paper contributes information that empowers teachers who strive to meet the challenges of making science more comprehensible to socio-economically and culturally diverse learners.

on teachers' subject matter, pedagogical knowledge and PCK per se but they are inherent in the teachers' classroom practices.

\section{Teachers' Orientations towards Science Teaching}

Teaching is a complex process that requires teachers to transform and apply knowledge from multiple domains; science teaching orientations have been found to be a critical component within the PCK of science teachers (Abell, Park Rogers, Hanuscin, \& Gagnon, 2009). There are various conceptions of science teachers' orientations or teachers' beliefs about science and science teaching and learning. Some of these conceptions include pedagogical orientation (Ramnarain \& Schuster, 2014); teaching orientation (Magnusson, Krajcik, \& Borko, 1999); teaching approach (Anderson \& Smith, 1987); conceptions of science teaching (Grossman,1990; Hewson \& Hewson, 1988); functional paradigms (Lantz \& Kass, 1987); world images (Wubbels, 1992); preconceptions of teaching (Weinstein, 1989); and approaches to teaching (Trigwell, Prosser, \& Taylor, 1994).

Teaching orientations are teachers' knowledge and beliefs about the purposes and goals of teaching science at a particular grade level; or simply a general way of viewing or conceptualising science teaching (Magnusson et al., 1999). In elaborating this definition, Friedrichsen, van Driel, and Abell (2011) conceptualised teaching orientations as beliefs that characterise goals, purposes of science teaching, and views about science teaching and learning, which include the nature of science and the nature of teaching and learning science. As a way of combining these definitions, Anderson and Smith (1987) referred to science teachers' orientation as a combination of teachers' cognition and action. Drawing on the different definitions above, the study conceived teachers' orientations as teachers' beliefs about the nature, goals and purposes of science, and how science teaching and learning occur in a particular learning environment such as a township school.

Magnusson et al. (1999) proposed nine different orientations to science teaching, namely:

- Process, where teachers engage learners in activities to develop thinking process

- Academic rigour, where teachers challenge learners with difficult problems and activities

- Didactical teaching through lecture or discussion, and questions directed to learners

- Conceptual change, where teachers engage learners in discussion and debate so that learners can construct valid knowledge claims

- Activity-driven teaching, where learners are involved in hands-on activities

- Discovery, where learners explore their thought process and interest

- Project-based science, where learners engage in investigative work to generate new information

- Guided inquiry, and open inquiry where learners are involved in identifying problems and solving them through investigations with and without teachers' guidance respectively.

These pedagogical orientations were used in analysing teachers' orientations in the study.

\section{Teaching Context in the Science Classroom}

The study conceptualised teaching context as the social environment portrayed in the science classroom due to learners' socio-cultural practices, experiences and beliefs that develop as a result of learners belonging to specific cultural groups and living within specific environmental and social settings. These are aspects of IKS. It is necessary for science teachers to recognise diversity in their classrooms, meaning the differences in ethnicity, home language, socio-economic status and culture among learners (Lee \& Luykx, 2006). Different cultures hold different norms, values and expectations which present strong influential guidelines on educational practices (Ho, Holmes, \& Cooper, 2004). In this regard, socio-cultural factors which include language used in the teaching and learning 
process; the learners' prior experiences; and their behaviour, attitudes and cultural values have been found to either facilitate or hinder learner interaction and active participation in class (Appleton \& Harrison, 2001; Wellington \& Osborne, 2001). As a result, science teachers face daunting challenges which, firstly, include recognising and understanding diverse learners' socio-cultural backgrounds in the classroom and, secondly, finding the most suitable ways to manage these differences for effective engagement of learners with science concepts.

Social context shapes the teachers' practice in terms of the kind of questions they ask, the ideas they reinforce, the tasks they assign to their learners and, most importantly, the teaching methods they will employ. Such a practice brings knowledge to the learners and assists them in understanding some of the problems in their communities or even explaining some of the issues or challenges they encounter in everyday experience. This is in accordance with the South African amended National Curriculum Statement (NCS) Grades R-12: Curriculum and Assessment Policy (CAPS) for Natural Sciences (DBE, 2011) which, in one of its aims, seeks to ensure that learners acquire and apply knowledge and skills in ways that are meaningful to their own lives. Specifically, the curriculum aims to equip learners irrespective of their socio-economic background with knowledge, skills and values that enable them to participate fully in society. In addition, as one of its principles, NCS values indigenous knowledge systems (IKS), acknowledging the rich history and heritage of the country, as important contributors to nurturing values. Such a stance brings to the fore aspects in science teaching which include the importance of NS teachers being knowledgeable about their learners' socio-cultural backgrounds and employing instructional strategies that engage learners in meaningful understanding. In addition, science teachers should always strive to gain skills to manage classroom discourse whereby learners' socio-cultural background is considered in teaching NS.

\section{Interaction of Context and Pedagogical Orientations}

Teachers' pedagogical orientations are an important teacher knowledge domain, particularly in this study because teachers' beliefs about science and science teaching have a strong bearing on the kind of learning experiences and activities they select when considering their teaching and learning context (Magnusson et al., 1999). Teachers' consideration of the teaching and learning environment entail integrating learners' socio-cultural practices, experiences and beliefs when teaching particular NS topics. Teachers' recognition of the teaching and learning environment (context) is a key requirement for meaningful presentation of science to Grade 9 township learners. Mavuru and Ramnarain (2017) noted that science teachers' knowledge of the teaching and learning context enables teachers to engage in multiple pedagogical and instructional strategies which make science more relevant to the learners.

Arguably, science reforms fail to cater for the unique situations within specific classroom contexts characterised by learners' diverse socio-cultural backgrounds (Sarrason, 1996; Windschitl, 2002) since they disregard the influence of particular institutional contexts and the role of individual classroom teachers. Smith and Southerland (2007) found that the effectiveness of reform efforts is largely dependent on teachers' ability or inability to modify their fundamental or central beliefs about what it means to teach and to learn science. Teachers' beliefs shape them as to who they are as science teachers; and therefore influence their instructional decisions (Smith, 2005). Some researchers also noted that teachers' beliefs or personal theories about teaching and learning inform the decisions they make concerning teaching methods and strategies as well as the content they select for their learners in a science classroom (Brickhouse \& Bodner, 1992; Smith, 2005).

Consequently, the success of any science reform programme depends on the teachers' ability to think differently about teaching and learning. This is because changing beliefs is thought to be a long-term sustained change in practice (Richardson, 1996). Because teachers invest emotionally and intellectually in their beliefs, they maintain their beliefs unless something challenges the existing beliefs the individual teacher holds (Pajares, 1992). There is also substantial evidence that deeply held subject-matter beliefs constrain science and mathematics teachers from adopting practices that conflict with their notions of what is appropriate science instruction (Fennema \& Franke, 1992; Laplante, 1997).

Knowing how to teach specific content to learners of various abilities and in various contexts is a complex process (Abell, 2007). This study did not disregard this complexity. Instead, it sought to examine what science teachers knew about their learners' socio-cultural practices, experiences and beliefs; and how best they could use such knowledge to make science more relevant, thereby engaging their learners for improved understanding. In addition, teachers' orientations to science teaching and learning were envisaged as an important teacher knowledge domain. Hence, the study explored how teachers' integration of the learners' socio-cultural practices, experiences and beliefs shapes teachers' pedagogical orientations to science teaching. The researchers' argument is that teachers' knowledge of learners' socio-cultural background (context) should enable them to teach science concepts in a more comprehensive manner that enhances learners' understanding of science concepts. By taking the stance of focusing on the social context, the understanding was that science teachers' knowledge about their learners' socio-cultural backgrounds lays a foundation upon which teachers may understand the learners' expectations, 
Table 1. Structure of teacher professional development

\begin{tabular}{|c|c|c|}
\hline Stage & Activities & Resources \\
\hline Before interviews & $\begin{array}{l}\text { - Discussing the study's conception of learners' socio-cultural background. } \\
\text { Brainstorming on the aspects of learners' socio-cultural practices, experiences } \\
\text { and beliefs }\end{array}$ & $\begin{array}{l}\text { Concept map showing the } \\
\text { aspects of learners' socio- } \\
\text { cultural background }\end{array}$ \\
\hline $\begin{array}{l}\text { Before lesson } \\
\text { observations }\end{array}$ & $\begin{array}{l}\text { - Identifying learners' socio-cultural practices, experiences and beliefs suitable } \\
\text { for incorporation in some NS topics } \\
\text { - Identifying suitable methods and activities for integrating learners' socio- } \\
\text { cultural practices, experiences and beliefs in NS teaching and practise using } \\
\text { them } \\
\text { - Planning lessons that incorporate learners' socio-cultural background in } \\
\text { some NS topics }\end{array}$ & $\begin{array}{l}\text { Curriculum documents, } \\
\text { lesson plans, learners' } \\
\text { textbook }\end{array}$ \\
\hline $\begin{array}{l}\text { After lesson } \\
\text { presentations. }\end{array}$ & $\begin{array}{l}\text { - Identifying the successes and failures of the previous lessons } \\
\text { - Evaluating the teaching strategies and activities used in the previous lessons } \\
\text { - Identifying ways of improving the upcoming lessons }\end{array}$ & $\begin{array}{l}\text { Video clips of lessons } \\
\text { observed }\end{array}$ \\
\hline
\end{tabular}

beliefs, attitudes, languages, systems and values that influence science teaching and the learning process (Suh, 2005).

This study, therefore, sought to answer the question: How does social context influence Grade 9 Natural Sciences (NS) teachers' pedagogical orientations at three township schools in South Africa?

\section{METHODOLOGY}

\section{Research Design}

The study employed a qualitative case-study research design, which allows an in-depth exploration of classroom practices, using multiple forms of data collection (Creswell, 2005). The emphasis in qualitative research is the key concept, idea, or process studied (Creswell, 2014). Using Yin (2003), a case-study design was suitable for the study because the focus was on answering how context influences Grade 9 NS teachers' pedagogical orientations to science teaching without manipulating their behaviour or the contextual conditions within the science classroom. The researchers sought to understand phenomena in context-specific settings (township schools), without manipulating the phenomenon of interest (Patton, 2002), but probed for deeper understanding rather than examining surface features (Johnson, 1995).

\section{Selection of Participants}

Using Patton's (2002) notion of purposeful sampling, three Grade 9 NS teachers (one female and two males), each from three different township schools, were selected for this study. The logic and power of this type of purposive sampling lay in selecting information-rich cases for in-depth study, yielding insights and in-depth understanding rather than empirical generalisations. This enabled the researchers to generate meaningful and relevant data that answered the research question (Patton, 2002). The teachers had each taught Grade 9 NS in the same school for at least three continuous years, in which time they had an opportunity to interact and familiarise themselves with the community. The teachers (pseudonyms: Tembi, Thobile and Nyiko) were of different ethnic backgrounds and spoke different home languages (Sipedi, IsiZulu and Tsonga respectively). Their teaching experience and ages ranged from 4 to 33 years, and from 26 to 58 years respectively, and all had a professional teaching qualification (BEd degree or higher diploma in Education) from different universities in South Africa. They had also been trained on how to integrate learners' socio-cultural background in their teaching in a five-day professional-development programme previously organised by the researchers as shown in Table 1. Hence, they had an interest in the study. Most importantly, their learners came from diverse backgrounds, in terms of ethnic origin, home languages (IsiZulu, IsiXhosa, Sesotho, Setswana and Sipedi) and socio-economic background as explained earlier; all this formed a rich backdrop for the exploration of the influence of context on teachers' pedagogical orientations.

The three selected schools are located in a township south-west of Johannesburg and are within a radius of approximately five kilometres from each other. Therefore, the schools are located in almost the same community and generally enroll learners from township and informal settlements, all of which are poor. The schools were all non-fee-paying schools and hence depended on government support in terms of resources. It is important to understand the nature of the schools and communities in which the study took place. This is because the influence of schools and communities is difficult to separate as there is often an overlap between the school's socio-economic profile and that of the community in which the learners reside (Masondo, 2013). 
Table 2. Description of the role of each subscale

\begin{tabular}{cll}
\hline Subscale Name & Description \\
\hline 1 & $\begin{array}{l}\text { Lesson design and } \\
\text { implementation }\end{array}$ & $\begin{array}{l}\text { Examined how the design and application of a lesson supported learner understanding by } \\
\text { determining how the teacher organised the lesson to address learners' preconceptions } \\
\text { from other classes and everyday experiences as opportunities to explore the topic or } \\
\text { concepts }\end{array}$ \\
\hline 2 & $\begin{array}{l}\text { Propositional } \\
\text { pedagogical knowledge }\end{array}$ & $\begin{array}{l}\text { Measured what the teachers knew, and how well they organised and presented material in } \\
\text { a learner-oriented setting }\end{array}$ \\
\hline 3 & $\begin{array}{l}\text { Procedural pedagogical } \\
\text { knowledge }\end{array}$ & $\begin{array}{l}\text { Measured the level at which learners were involved in scientific ways of thinking (predicting, } \\
\text { estimating, hypothesising, negotiating ideas, and alternative ways of reasoning) as this is } \\
\text { vital for developing critical-thinking skills in learners }\end{array}$ \\
\hline 4 & $\begin{array}{l}\text { Learner-learner } \\
\text { interaction }\end{array}$ & $\begin{array}{l}\text { Assessed the level at which learners actively communicated with one another as they } \\
\text { explained their ideas and evaluated the ideas of others, which develops learners' critical- } \\
\text { thinking skills }\end{array}$ \\
\hline 5 & $\begin{array}{l}\text { Learner-teacher } \\
\text { interaction }\end{array}$ & $\begin{array}{l}\text { Examined how the teacher fostered a culture where learners were comfortable to ask } \\
\text { questions and had control over their own learning process }\end{array}$ \\
\hline
\end{tabular}

\section{Data Collection}

For each teacher, three pre-lesson and three post-lesson interviews were conducted using a semi-structured interview schedule. Five lessons were observed for each teacher using the Reformed Teaching Observation Protocol (RTOP) (Sawada, Piburn, Falconer, Turley, Benford, \& Bloom, 2000). This protocol is an observational instrument used by mathematics and science evaluators of professional-development projects to observe classroom content implementation, classroom culture and learner participation (Sawada et al., 2000). The instrument has five subscales and is calibrated with five indicators from 0 , which means 'never occurred', to 4 , which means 'very descriptive'. Table 1 shows the description of each subscale.

A non-participant observation method was used to capture real classroom practices hence providing a complete picture. Each teacher was observed whilst teaching concepts on reproduction, blood circulation, nutrition and energy. Only some aspects of the concepts taught on reproduction and other different topics had been discussed during professional development but the rest were simply according to the schools' work plan. Thus, there were a total of nine pre-lesson interviews, 15 lesson observations and nine post-lesson interviews for the three teachers. Teachers' reflections provided a means through which researchers could determine teachers' thinking in terms of their pedagogical orientations and practice.

\section{Data Analysis}

Video and audio recordings of the lessons, as well as the pre- and post-lesson interviews, were analysed using the constant comparative method (Merriam, 1998), which allowed for themes and patterns to emerge from the multiple sources of evidence. Analysis involved identifying evidence of any of Magnusson et al.'s (1999) nine different orientations. Data collection and analysis occurred concurrently to enable collection of adequate and relevant data (Baxter \& Jack, 2008), to answer the research question: How does social context influence Grade 9 NS teachers' pedagogical orientations at three township schools in South Africa? This also enabled the researchers to build coherence during the data-interpretation process (McMillan \& Schumacher, 2001).

Analysis began with the first interviews and observations and field notes as they were made; this occurred daily throughout the research process. This included the writing of conceptual memos which gave theoretical insights that emerged from the researcher's interpretation of the field notes. After repeatedly reading the interview transcripts and field notes, and reviewing the videotaped classroom observations, emergent patterns or trends were identified, coded using Saldana's (2009) manual coding system and then linked to representative quotes or incidences. These themes or 'recurring regularities' were first identified separately for each teacher for the lessons taught and interviews. The three cases (teachers), Tembi, Thobile and Nyiko, were later compared in a cross-case analysis. Similar codes and categories from one data set were merged with those from other data sets. Any discrepancies identified required that the researcher recode the data or even engage the participants to ascertain what they meant if it were interview data, or what they intended to do if it were data from lesson observations. As a result, two common themes were identified. 
Table 3. Coding and analysis of data from lesson observations

\begin{tabular}{|c|c|c|}
\hline Codes & Categories & Emerging themes \\
\hline $\begin{array}{l}\text { i) Value alternative ways of solving } \\
\text { problems } \\
\text { ii) Use of learners' prior knowledge and } \\
\text { experiences } \\
\text { iii) Exploring learners' belief systems } \\
\text { iv) Use of learners' practices } \\
\text { v) Community involvement } \\
\text { vi) Use of different representations } \\
\text { vii) Prediction of results of investigations }\end{array}$ & $\begin{array}{l}\text { i) Investigations involving classifying sources of } \\
\text { energy learners use at home } \\
\text { ii) Constructing models and different ways to present } \\
\text { concepts and results } \\
\text { iii) Peer coaching among the learners } \\
\text { iv) Involving learners in an activities to identify } \\
\text { positions of structures struck by lightning. } \\
\text { v) Performing food tests using traditional food items } \\
\text { from different ethnic groups. }\end{array}$ & $\begin{array}{l}\text { Teacher involvement of } \\
\text { learners in hands-on activities }\end{array}$ \\
\hline $\begin{array}{l}\text { i) Exploring the use of different strategies } \\
\text { ii) Outlining procedural instructions in } \\
\text { some cases } \\
\text { iii) Involving learners in enacting their } \\
\text { thought processes } \\
\text { iv) Learners constructing knowledge } \\
\text { v) Teacher enhancing learner } \\
\text { investigations } \\
\text { vi) Teachers listening to learners' ideas } \\
\text { vii) Content integration with other } \\
\text { disciplines } \\
\text { viii) Learners trying different ways to } \\
\text { understand concepts }\end{array}$ & $\begin{array}{l}\text { i) Exploring beliefs on lightning, witchcraft, curses } \\
\text { and ancestral spirits when teaching concepts on } \\
\text { reproduction such as fertility and surrogacy. } \\
\text { ii) Employing argumentation as a strategy when } \\
\text { teaching male reproductive system and circumcision } \\
\text { iii) Using authentic problems and learners' everyday } \\
\text { life experiences for discussion in class } \\
\text { iv) Providing opportunities for learners to reflect and } \\
\text { evaluate their original ideas based on the newly } \\
\text { acquired knowledge } \\
\text { v) Teacher using prompts and open-ended questions } \\
\text { vi) Knowledge construction involved negotiation } \\
\text { between different ideas }\end{array}$ & $\begin{array}{l}\text { Teachers involving learners in } \\
\text { reflecting and evaluating the } \\
\text { relationship between their } \\
\text { socio-cultural practices, } \\
\text { experiences and beliefs and } \\
\text { scientific knowledge. } \\
\text { Teachers involving learners in } \\
\text { process-oriented learning }\end{array}$ \\
\hline
\end{tabular}

Table 4. Coding and analysis of data from interviews

\begin{tabular}{|c|c|c|}
\hline Codes & Categories & Emerging themes \\
\hline $\begin{array}{l}\text { i) Plan authentic problems } \\
\text { ii) Teachers plan content beyond the } \\
\text { level of the grade } \\
\text { iii) Thought-provoking activities } \\
\text { iv) Questions requiring critical thinking }\end{array}$ & $\begin{array}{l}\text { i) Content and activities that consider learner } \\
\text { involvement and use of the socio-cultural } \\
\text { knowledge, experiences and practices } \\
\text { ii) Teacher preparation of higher-level content in } \\
\text { anticipation to explain learners' ideas. } \\
\text { iii) Engaging learners in thought-provoking } \\
\text { discussions and promoting critical thinking }\end{array}$ & $\begin{array}{l}\text { Planning authentic teaching } \\
\text { and learning experiences that } \\
\text { are process-oriented and } \\
\text { activity-driven }\end{array}$ \\
\hline $\begin{array}{l}\text { i) Active role of learners in the learning } \\
\text { process } \\
\text { ii) More teacher-learner interactions } \\
\text { iii) Engaging learners in alternative } \\
\text { activities } \\
\text { iv) Learners respecting and appreciating } \\
\text { each other's contributions }\end{array}$ & $\begin{array}{l}\text { i) Ideas originating from the learners } \\
\text { ii) Learners involved in intense discussions that } \\
\text { questioned the conventional ways of doing things } \\
\text { iii) Learners exploring alternatives ways of solving } \\
\text { problems and questioning teacher methods } \\
\text { iv) Learners' appreciating each other's contributions } \\
\text { towards understanding of scientific concepts }\end{array}$ & $\begin{array}{l}\text { Reflecting on the goals and } \\
\text { purposes of science teaching } \\
\text { and learning as that of making } \\
\text { learners understand and apply } \\
\text { knowledge and skills in their } \\
\text { lives }\end{array}$ \\
\hline
\end{tabular}

\section{RESEARCH FINDINGS}

The purpose of the study was to explore how the teaching and learning context influences Grade 9 NS teachers' pedagogical orientations at three township schools in South Africa. In analysing data from both interviews and lesson observations, teachers showed how they designed thought-provoking teaching and learning activities and discussions that promoted critical thinking. Teachers employed teaching approaches and strategies that valued learners' ideas and stimulated them to question conventional ways of doing things, thereby exploring alternative ways of solving problems. Analysis of the data revealed that learners' socio-cultural practices, experiences and beliefs influenced teachers' pedagogical orientations in two important ways. Firstly, teachers' orientations to science teaching became more process-driven and activity-driven, which in turn influenced what specific content they chose to teach, and determined the approaches they used in science instruction. Secondly, teachers' views about the goals and purposes of science teaching changed from simply covering the curriculum requirements and preparing learners for examinations to that of building learner confidence, developing learner appreciation for the usefulness of science in their lives, gaining understanding and motivating learners to continue studying science.

Theme 1: Integration of learners' socio-cultural practices, experiences and beliefs influenced the teachers' views about the goals and purposes of science teaching, from that of content coverage when preparing learners for examinations to that of making science more relevant and applicable to the learners' lives beyond the science classroom. 
The three science teachers, Tembi, Thobile and Nyiko acknowledged the importance of considering learners' poor socio-economic background when designing their teaching so that every learner in the class would be considered. As such, they selected and used examples familiar to learners, and also made efforts to consider and understand the learners' feelings and situations where possible. The teachers therefore set realistic submission deadlines of learner projects and work done at home, particularly knowing that learners came from informal settlements where there was neither electricity nor internet facilities. Because teachers allowed learners to bring in and articulate their various experiences, teachers were cautious not to side-line or marginalise input from some of the learners. They structured their lesson content, activities and examples that took note of, and also addressed, learners' everyday experiences related to the scientific concepts taught. The focus of the teachers' practices changed from simply teaching curriculum science concepts as outlined, to that of facilitating learner understanding, building learner confidence, developing learner appreciation for the usefulness of science in their lives, and motivating learners to continue studying science. The following sections show how teachers achieved this.

\section{Use of Socio-economic Disadvantage as a Resource in Teaching Forms and Sources of Energy}

Teachers strongly acknowledged the importance of being knowledgeable about their learners' living conditions and challenges. They were positive that the various experiences learners go through at home provide rich resources when teaching certain topics such as energy. In a pre-lesson interview, teachers were asked about the role of knowledge of learners' socio-economic background in their teaching and gave the following responses:

Tembi: $\quad$ Because some learners have coal stoves, fires and paraffin at home and others come from informal settlement [name supplied] and have solar panels installed for them, this becomes so easy when we talk about renewable and non-renewable sources.

Thobile: We talk about sources of heat where some learners mention heaters to warm themselves in winter and the other group mentions ' mbaula' [coal heater], cookers for cooking and coal stoves for the same function.

Both teachers indicated that their learners understand well when teaching concepts using such familiar examples. Tembi indicated that her teaching also becomes much easier when she employs resources and examples familiar to the learners. She mentioned that the teaching of the concept of renewable energy with the use of resources familiar to learners was far easier and more palatable to learners than handling the topic on nuclear energy, which is difficult for the learners to conceptualise, since it is unfamiliar. The teacher elaborated that no matter how many examples or cases she used to make learners understand the idea of nuclear energy, the learners always showed lack of understanding as they would regurgitate information from their notes word-for-word when answering examination questions. This was contrary to how the learners answered questions on renewable energy when sources were familiar to them.

The above discussion shows that it is important to note that familiarity with learners' background made it easier for the teachers to relate to learners' experiences during the teaching and learning process. The teachers did not view learners' poor backgrounds as barriers to the teaching and learning of science. Instead, they embraced them and used them as platforms to make learners understand sources of energy.

\section{Use of Analogies to Teach Blood Circulatory System to Learners who Believed in Blood as a Sacred Substance}

In an effort to make science concepts more understandable to their learners, the teachers used different analogies and approaches to teach the blood circulatory system. For instance, Nyiko asked learners about their socio-cultural practices or beliefs that are associated with blood and its movement in the body. Many learners pointed out that they had witnessed the slaughtering of animals such as goats for rituals and the blood used to cleanse any evil spirits in the home and family. Nyiko questioned how blood can perform such a function. One learner said: 'Sir, blood is stored in the heart and the heart is full of love.' Other learners laughed but some believed him and added that smearing blood around the home is like spreading love which repels evil. It shows how learners try to explain their cultural practices using common sense. This was complicated by a learner who pointed out that a 'sangoma', meaning a traditional healer, once smeared blood on his older family members in order to scare witches away and others said that it was meant to give them strength. These learners viewed blood as a sacred substance, due to their socio-cultural practices and beliefs.

Nyiko asked those learners how blood can transport oxygen which is required by all body tissues if it is stored in the heart in response to one of the learners' responses above. Such learner 'conceptions' only surfaced because 
the teacher allowed them to share what they knew before exploring the concept. In reaching out to learners, Nyiko drew on learners' everyday experience when he used an analogy to explain the movement of oxygenated and deoxygenated blood in the human blood. Analogies help learners relate the scientific concepts learnt to familiar and relevant experiences and knowledge. This is what the teacher said:

Nyiko: You see we have roads, streets and paths where we walk and drive our cars, the same applies in the circulatory system, the veins and arteries are the roads and streets. We have roads where cars move in one direction and the others move in another direction. The same applies to deoxygenated and oxygenated blood which moves in different blood vessels.

These were some of the learners' remarks: 'Ooh, that's it' 'Yes, that makes it clear'. Nyiko jokingly said: 'Though blood is such a magical substance as indicated by some of your experiences, it is still a medium of transport in our bodies.' It shows that certain concepts are abstract for learners to conceptualise, so using examples familiar to them enhances learner understanding. Analogies could also dispel some of the socio-cultural beliefs learners hold which can impede the acquisition of proper scientific concepts. The analogy used drew on an experience that most learners are familiar with, the roads and stream of vehicles travelling on the same road in different directions and carrying different people and goods. However, it should be noted that this analogy helps learners when the sole purpose is to demonstrate the element of direction of flow of blood, and the need for blood vessels. It also demonstrates that as blood circulates it carries different components much like cars, buses and even motorcycles moving along the same highway. However, learners may end up thinking that oxygenated and deoxygenated blood carries the same substances since roads generally have similar vehicles. Learners may also think that blood movement stops at certain points in the vessels as cars do at robots. In addition, nothing is said about the need for a pumping mechanism that makes the movement continuous and in this case, the place of the heart in the circulation system.

In order to make sure that the learners correctly connect the circulatory system to the system of vehicles on the road, Nyiko asked learners to identify features in the road system that correspond with those in the circulatory system. The learners shared information in pairs. One pair asked: 'Sir what do drivers in the cars represent?' Nyiko involved one learner who answered: 'It is the heart.' This meant that there were many hearts in the human body, a misconception which some learners would carry away unless addressed. Failure by teachers to appropriately lead learners to map features of an analog with features of a target (concepts) could result in learners misunderstanding the concept being taught. Through discussions, the teacher and the learners later agreed that the driver in each vehicle is like the force in each blood vessel which causes movement of the vehicle and goods, in the same way that there is force that propels blood throughout the blood vessels. It was important for the teacher to explain to the learners that an analogy helps to understand some aspects of the concept but not all.

Theme 2: Integration of learners' socio-cultural practices, experiences and beliefs influenced teachers' orientations to science teaching in that their teaching became more process- and activity-driven.

Because teachers were knowledgeable about learners' socio-cultural practices, experiences and beliefs, they made efforts where possible to harmonise the conflict between learners' worldviews and science. The teachers' focus was on facilitating learner understanding of concepts. They designed their teaching in such a way that learners were involved in process- and activity-oriented learning. It was commendable to observe how each individual teacher formulated completely different activities and engaging learners in experiences different from those used during professional development or adapting familiar ones to suit their classroom contexts. In fact, incorporating learners' socio-cultural practices and beliefs made teachers modify their teaching strategies, explore different ways of explaining concepts, design experiments and improvise in order to enhance learners' understanding. Science teaching was contextualised and done specifically for a particular group of learners. When asked about how they would use the knowledge brought in by the learners, the three teachers pointed out that: firstly, they would explore learners' experiences before dismissing them; and, thereafter, they would adjust their instructional approaches to the benefit of the learners. It means therefore that these teachers would always be willing to adopt suitable strategies and prepare activities which engage learners fully in the learning process. They used scientific explanations that relate to learners' worldviews, thereby harmonising the conflict between learners' belief systems and science knowledge where possible. One of the teachers, Tembi, pointed out that her teaching of scientific concepts helps learners understand and makes them dismiss or make sense of their previously held ideas. It should be noted that the teachers acknowledged the role of professional development in equipping them with knowledge and skills of making concepts more comprehensible to their learners. Teachers also expressed their uneasiness in discussing scientific concepts and learners' opinions that conflict with their own beliefs and practices. An example is of Tembi (a staunch Jehovah's Witness), who felt that she was compromising her religious beliefs particularly when teaching about abortion and contraceptives under the topic reproduction, which learners showed much interest in. 


\section{Involvement of Community Members in the Teaching and Learning of Fertility in Women and Different Forms of Contraception}

It was quite notable that Indigenous Knowledge Systems (IKS) were often brought into the science classrooms which compelled the teachers to explore different ways of presenting science concepts. Learners' indigenous knowledge on causes of infertility and traditional methods of contraceptives encouraged teachers to create partnerships with community members and facilities, such as clinics and resources that provided learners with access to knowledge and experiences that extend and complement learning experiences in a science classroom. In this regard, the teachers acknowledged the community role in building up scientific knowledge. The teachers pointed out that they always encourage learners to discuss the science concepts they learn at school with their parents and other adult community members at home. The teachers ascertained learners' pre-instructional knowledge arising from their socio-cultural practices, experience and beliefs as the basis for teaching new content. Ascertaining learners' pre-instructional knowledge prevented distortion of new concepts in cases where prior knowledge from their socio-cultural practices, experiences and beliefs conflicted with new content (Mansour, 2010), as learners tend to transform meaning based on previous knowledge (Upadhyay, 2005).

\section{Allowing Learners to Share Everyday Experiences during the Teaching and Learning Process}

Sometimes teachers did not probe for any beliefs or experiences learners had regarding the topic being taught; instead learners would ask questions to ascertain some of the anomalies they experience in their communities. For example, in a lesson on reproduction in humans, a learner from Tembi's class inquired, 'what is the length of pregnancy in humans?' which some of the learners thought was obvious. The learner pursued her issue when she queried whether it does not depend on the individual since her cousin was pregnant for a year. Another learner concurred as she pointed out that her neighbour always has pregnancies whose period stretched way beyond nine months. One learner shouted, 'Bamuthakathile!' meaning they bewitched her. The teacher allowed learners to discuss it among themselves, which gave the teacher time to recollect and identify the most plausible explanation to give to the learners. At the end, the learners were asked to identify the gestation periods of different animals. In those discussions the learners realised that the information on the gestation periods of other animals was a result of observations and experiments in the same way the gestation period of humans was determined. When asked in the post-lesson interview about the witchcraft issue mentioned in the lesson, the teacher hoped the activity and discussion about explaining the anomaly could have dispelled such beliefs. She was not, however, certain about that. On that note, one of the teachers honestly explained.

Nyiko: To be honest with you when it comes to things involving witchcraft, I cannot help the learners much because I also don't understand whether it really happens or not.'

\section{Use of Argumentation in Harmonising the Two Knowledge Domains, Learners' Worldviews and Science Knowledge}

In a lesson that followed after exploring the causes of infertility, Thobile asked learners to discuss the following: In some countries some women are paid to donate eggs that scientists can use in their studies; is it a good thing? One boy said, 'amaeggs azopela', meaning eggs will be depleted. The teacher responded by asking, 'How many eggs can a 30-year-old woman produce every month for 10 years?' This was meant to show learners that quantity was not an issue here. Some learners argued from an African traditional perspective when they said, 'Such women will fail to reproduce again'. The teacher inquired how that is possible. One learner retorted, 'The ancestors will be angry, they are the ones who give you all the blessings'. The teacher's question, 'How can scientists research on reproductive diseases if there are no egg donors?' triggered class discussions to support critical thinking. Another learner said, 'Those women who donate eggs should not be paid at all since they are helping out'. In addition, some learners started discussing the different reproductive diseases in their families and communities and how scientific knowledge has helped in curbing such conditions. This kind of teaching made learners aware of the need to gather enough information that they can use to make well-grounded decisions, which is an aspect of teaching critical and analytical skills. The teacher's provision of an authentic problem stimulated learners to be actively engaged in the learning process and challenged them intellectually. They realised that sometimes they cannot follow their sociocultural beliefs and practices without assessing the pros and cons as they realised that their current ideas cannot solve the problem at hand (Goodrum, Hackling, \& Rennie, 2002).

As a result, argumentation facilitated the active participation of learners, with the teachers even acknowledging in the post-lesson interviews how their classroom discourse had changed ever since they started incorporating context in their teaching. In addition, this encouraged learner knowledge construction in that each time one learner introduced their ideas, the others would use that information to improve their own line of argument which meant 
that, in the end, the desired concepts would be grasped. Throughout the process, the teachers were inculcating the tenets of the nature of science in their teaching, such as the tentative nature of scientific knowledge and its subjectivity, as different learners' views were considered based on the merit of their evidence or reasoning.

\section{Classifying and Performing Food Tests using Traditional Food Items from Different Ethnic Groups}

In a lesson on nutrition, Thobile tasked learners to identify one family member or neighbour and identify what they ate and the quantities they required. Thobile tasked learners to analyse the diet in terms of whether it was healthy or not. In particular, learners needed to identify the socio-cultural practices, experiences and beliefs of the person, as people from different cultures or ethnic groups have their specific food preferences. They were also tasked to compare the diet with that of the learner from the suburbs (more socio-economically advantaged community). The learners would then determine the missing food types or remove the unwanted ones in order to make it a healthy diet. Such an activity helped to conscientise learners of the importance of healthy diets and that the palatability of food does not necessarily transform into required nutrients. The teacher explained in a postlesson interview that his learners tend to bring in the salted and sweet food items to school, which are unhealthy.

In a related lesson, Nyiko also assigned learners a project on classifying their own traditional food into the different main classes as outlined in the curriculum. Table 4 shows some of the types of diet that the class compiled together after presenting their different traditional food items in class.

The table shows that different ethnic groups have different traditional diets which can be classified into different food groups. The teacher helped learners to apply the knowledge they had learnt about healthy diet to classify their own traditional food.

In a practical activity, Thembi involved learners in carrying out food tests using some of the traditional food brought by learners. In this practical activity learners were excited as they were sceptical about some of the traditional food brought by others. In this way the learners realised that even traditional food has nutrients which are important for the body. Thembi indicated in a post-lesson interview that the activity helped learners appreciate their own culture and those of others and dispelled the inferiority complexes normally displayed in classes due to different ethnic origins and different socio-economic backgrounds. These findings are an indication of the need for teachers to acknowledge and incorporate diverse learners' socio-cultural backgrounds as most learners would feel a sense of belonging to a community of science learning. Importantly, it helps the teacher to embrace every learner so that no learner would feel marginalised or left out. In showing the importance of such a harmony, Aikenhead and Jegede (1999) maintained that learners' success in science is dependent on how learners perceive cultural differences between their lived experiences and those in the science classroom. Teachers should therefore carefully assist learners to connect what they experience at home with the new content learnt in the science classroom (Aikenhead \& Jegede, 1999).

In spite of the teachers' practices, they expressed reservations about integrating social context into their teaching of every topic. In addition to always making efforts to understand the interaction between IKS and Western science and at the same time their ability to manage such classroom discourses, teachers expressed concerns that intense discussions in class consumed too much time to allow coverage of content within the stipulated time frame. These results are corroborated by the findings from Mensah's (2011) study where the teachers acknowledged the challenges of incorporating their learners' socio-cultural practices, experiences and beliefs in order to connect science to real life. However, Thembi, the youngest and least experienced teacher was more adventurous and took an initiative to engage learners in discussions of issues that are normally shied away from, and this improved learner participation and their eagerness to learn more.

\section{DISCUSSION AND IMPLICATIONS}

Teachers' knowledge about the teaching and learning context influenced their orientations to science teaching in that their teaching became more process- and activity-driven. Science teachers' orientations to science teaching have been found to be a critical component within the PCK of science teachers. The research findings show that context influenced teachers to reframe the instruction of NS as a social process of knowledge construction rather than as a body of factual information provision. As a result, the teachers repositioned their role as that of facilitator of learning and not as source of knowledge (Meyer \& Crawford, 2011). Only two of the orientations by Magnusson et al. (1999) were identified and the other seven - academic rigour, didactic, conceptual-change, discovery, projectbased science, open inquiry and guided inquiry - were not. This could be because of the nature of the concepts taught or the limited number of lessons observed. In some cases there were elements of inquiry but were not really explored much in the lessons presented to warranty reporting. 
Teachers made efforts to provide opportunities for learners to discover information on their own through exploring, hands-on activities and enactment of learnt science concepts. These process-oriented lesson presentations specifically related to learners' prior knowledge, helped learners to change their conceptions (Abrams \& Hogg, 1998). This agrees with the social constructivist notion that science teachers' attention should be on the process of science rather than just the content (Leach \& Scott, 2008). As Basili and Sanford (1991) contended, if learners understand the process of science, they are better equipped to acquire knowledge on their own. The results of the study showed that engaging learners during the teaching and learning process helped teachers to ascertain learners' difficulties which forced them to design appropriate instruction. Such tailor-made instruction was found to improve learner performance in other studies (Savinainen \& Scott, 2002), as learners would engage more with the material to be learnt.

The research findings provide insights and implications to both in-service and pre-service teacher development programmes. Teacher educators should create a context where prospective teachers are engaged, challenged and stimulated to reflect upon their personal conceptions and ideas (Thomas \& Pedersen, 2003). Notably, these beliefs influence the teachers' acquisition of new knowledge, its interpretation and organisation (Mansour, 2010). It therefore justifies teacher educators' role in designing their curricula with a focus on helping teachers to modify their pedagogical orientations that suit the kind of teaching and learning environment in which they are likely to work.

In particular, teacher educators should teach with a focus on exploring the different contexts that their preservice teachers would work in after qualification. As such, these pre-service teachers would be engaged in a process of repositioning their pedagogical orientations throughout their teacher professional development. In this way, the teachers' orientations to science teaching would be challenged and reconstructed throughout their studies. A point to note is that teacher beliefs/ orientations to science teaching have been found to be tacit, enduring and changing them is thought to be a long-term sustained change in practice (Abell, 2007; Richardson, 1996). In addition, prospective teachers' beliefs were found to act as filters in preventing them from considering unfamiliar and discrepant ideas (Kellner, Gullberg, Attorps, Thorẽn, \& Tärneberg, 2011; Thomas \& Pedersen, 2003), hence the need to explore them during teacher professional development. Overall, this would have a positive influence on the development of other teacher knowledge domains (subject matter knowledge, pedagogical knowledge and PCK) (Magnusson et al., 1999).

Teachers' knowledge of the teaching context influences teachers to employ pedagogical approaches which Bennett, Hogarth, and Lubben (2003) described as context-based, applications-led, or as approaches that promote links between science-technology and society (STS). This calls for in-service teacher professional-development programmes to consider exploring orientations of practising science teachers in different teaching contexts with the hope of assisting teachers redefine their beliefs about the goals and purposes of science teaching. This is particularly pertinent in South Africa, where educational reform envisions schooling in which all learners, irrespective of their background, have the opportunity to succeed (Frempong, Reddy, \& Kanjee, 2011).

\section{REFERENCES}

Abell, S. K. (2007). Research on science teacher knowledge. In S. A. Lederman, (Eds.), Handbook of research on science education (pp. 1105-1150). Mahwah, NJ: Lawrence Erlbaum Associates.

Abell, S. K., Rogers, P., Hanuscin, D. L., Lee, M. H., \& Gagnon, M. J. (2009). Preparing the next generation of science teacher educators: A model for developing PCK for teaching science teachers. Journal of Science Teacher Education, 20(1), 77-93. https:/ / doi.org/10.1007/s10972-008-9115-6

Abrams, D., \& Hogg, M. A. (1998). Prospects for research in group processes and intergroup relations. Group Processes and Intergroup Relations, 1, 7-20. https:/ / doi.org/10.1177/1368430298011002

Aikenhead, G. S., \& Jegede, O. J. (1999). Cross-cultural science education: A cognitive explanation of a cultural phenomenon. Journal of Research in Science Teaching, 36, 269-287. https://doi.org/10.1002/(SICI)10982736(199903)36:3<269::AID-TEA3>3.0.CO;2-T

Anderson, C. W., \& Smith, E. L. (1987). Teaching science. In V. Richardson-Koehler (Ed.), Educators' handbook: A research perspective (pp. 84-111). New York: Longman.

Appleton, K., \& Harrison, A. (2001). Outcomes-based science units that enhance primary and secondary science teachers' PCK. Fremantle: Paper presented at the Australian Association for Research in Education (AARE) Conference.

Basili, P. A., \& Sanford, J. P. (1991). Conceptual change strategies and cooperative group work in chemistry. Journal of Research in Science Teaching, 28(4), 293-304. https:/ / doi.org/10.1002/tea.3660280403

Baxter, P., \& Jack, S. (2008). Qualitative case study methodology: Study design and implementation for novice researchers. The Qualitative Report, 13(4), 544-559. 
Bennett, J., Hogarth, S., \& Lubben, F. (2003). A systematic review of the effects of context-led and ScienceTechnology-Society (STS) approaches in the teaching of secondary science. Version 1.1 In Research evidence in education library. London: EPPICentre, Social Science Research Unit, Institute of Education.

Brickhouse, N., \& Bodner, G. M. (1992). The beginning science teacher: Classroom narratives of convictions and constraints. Journal of research in science teaching, 29(5), 471-485. https:// doi.org/10.1002/ tea.3660290504

Bush, T., \& Heystek, J. (2003). School governance in the new South Africa. Compare, 3, $127-138$. https:// doi.org/10.1080/0305792032000070084

Chisholm, L., \& Sujee, M. (2006). Tracking racial desegregation in South Africa Schools. Journal of Education, 40, 441159.

Çimer, A. (2007). Effective teaching in science: A review of literature. Journal of Turkish Science Education, 4(1), 2044.

Creswell, J. (2005). Educational research: Planning, conducting, evaluating quantitative and qualitative Research (2nd ed.). Upper Saddle River, NJ: Pearson Education.

Creswell, J. W. (2014). Research design: Qualitative, quantitative, and mixed methods approaches (4th ed.). California: Sage Publications Inc.

Department of Basic Education (DBE). (2011). National Curriculum Statement (NCS) Grades 9-12. Republic of South Africa: Department of Education. Pretoria: Government Printer.

Fennema, E., \& Franke, M. L. (1992). Teachers' knowledge and its impact. In D. A. Grouws (Ed.), Handbook of research on mathematics teaching and learning (pp. 147-164). New York, NY: Simon \& Schuster Macmillan.

Frempong, G., Reddy, V., \& Kanjee, A. (2011). Exploring equity and quality education in South Africa using multilevel models. A Journal of Comparative and International Education, 41(6), 819-835. https:/ / doi.org/10.1080/03057925.2011.607488

Friedrichsen, P. J., Van Driel, J. H., \& Abell, S. K. (2011). Taking a closer look at science teaching orientations. Science Education, 95(2), 358-376. https://doi.org/10.1002/sce.20428

Goodrum, D. H., Hackling, M., \& Rennie, L. (2002). The status and quality of teaching and learning of science in Australian schools. Department of Education, Training and Youth Affairs: Canberra.

Grossman, P. L. (1990). The making of a teacher: Teacher knowledge and teacher education. New York, NY: Teachers College Press.

Hammett, D. (2008). Disrespecting teacher: The decline in social standing of teachers in Cape Town, South Africa. International Journal of Educational Development, 28,340-347. https:/ / doi.org/10.1016/j.ijedudev.2007.05.007

Hewson, P. W., \& Hewson, M.G. (1988). An appropriate conception of teaching science: A view from studies of science learning. Science Education, 72(5), 597-614. https:/ / doi.org/10.1002/sce.3730720506

Ho, E., Holmes, P., \& Cooper, J. (2004). Review and evaluation of international literature on managing cultural diversity in the classroom. Prepared for the Ministry of Education and Education New Zealand. University of Waikato.

Johnson, S. D. (1995). Will our research hold up under scrutiny? Journal of Industrial Teacher Education, 32(3), 3-6.

Jones, M. G., \& Carter, G. (2007). Science teacher attitudes and beliefs. In S. K. Abell \& N.G. Lederman (Eds.), Handbook of research on science education (pp. 1067-1104). Mahwah, NJ: Erlbaum.

Kellner, E., Gullberg, A., Attorps, I., Thorẽn, I., \& Tärneberg, R. (2011). Prospective teachers' initial conceptions about pupils' difficulties in science and mathematics: A potential resource in teacher education. International Journal of Science and Mathematics Education, 9, 843-866. https:/ / doi.org/10.1007/s10763-010-9232-5

Lantz, O., \& Kass, H. (1987). Chemistry teachers' functional paradigms. Science Education 71(1), 117-134. https:// doi.org/10.1002/sce.3730710114

Laplante, B. (1997). Teachers' beliefs and instructional strategies in science: Pushing analysis further. Science Education, 81, 277-294. https:/ / doi.org/10.1002/(SICI)1098-237X(199706)81:3<277::AID-SCE2>3.0.CO;2-A

Leach, J., \& Scott, P. (2008). Designing and evaluating science teaching sequences: An approach drawing upon the concept of learning demand and a social constructivist perspective on learning. Studies in Science Education, 38(2002), 115-142. https:/ / doi.org/10.1080/03057260208560189

Lee, O., \& Luyks, A. (2006). Science education and student diversity: Synthesis and research agenda. New York, NY: Cambridge University Press. https://doi.org/10.1017/CBO9780511617508

Little, J. W. (2003). Inside teacher community: Representations of classroom practice. Teachers College Record, 105, 913-945. https:/ / doi.org/10.1111/1467-9620.00273 
Magnusson, S., Krajcik, J. S., \& Borko, H. (1999). Nature, sources and development of pedagogical content knowledge for science teaching. In J. Gess-Newsome \& N. G. Lederman (Eds.), Examining pedagogical content knowledge (pp. 95-132). Dordrecht: Kluwer.

Mansour, N. (2010). Impact of the knowledge and beliefs of Egyptian science teachers in integrating an STS based curriculum: A socio-cultural perspective. Journal of Science Education, 21, 513-534. https:/ / doi.org/10.1007/s10972-010-9193-0

Masondo, G. (2013). The race connections in South African Education. Naptosa Insight, 7(2), 14-16.

Mavuru, L., \& Ramnarain, U., (2017). Teachers' knowledge and views on the use of learners' socio-cultural background in teaching natural sciences in Grade 9 township classes. African Journal of Research in Mathematics, Science and Technology Education, 21(2), 176-186. https:// doi.org/10.1080/18117295.2017.1327239

McMillan, J. H., \& Schumacher, S. (2001). Research in education. A conceptual introduction (5th ed.). New York, NY: Longman.

Mensah, F. M. (2011). A case for culturally relevant teaching in science education and lessons learned or teacher education. The Journal of Negro Education, 80(3), 296-309.

Merriam, S. B. (1998). Qualitative research and case study applications in education. San Francisco, CA: Jossey-Bass.

Meyer, X., \& Crawford, B. A. (2011). Teaching science as a cultural way of knowing: Merging authentic inquiry nature of science, and multicultural strategies. Cultural Studies of Science Education, 6(3), 525-547. https:/ / doi.org/10.1007/s11422-011-9318-6

Odora-Hoppers, C. A. (2001). Indigenous knowledge systems and academic institutions in South Africa. Perspectives in Education, 19(1), 73-85.

Onwu, G., \& Stoffels, N. (2005). Instructional functions in large, under-resourced science classes: Perspectives of South African teachers. Perspectives in Education, 23, 79-91.

Pajares, M. (1992). Teachers' beliefs and educational research: Cleaning up a messy construct. Review of Educational Research, 62, 307-322. https://doi.org/10.3102/00346543062003307

Patton, M. Q. (2002). Qualitative evaluation and research methods (3rd ed.). Thousand Oaks: SAGE.

Prinsloo, E. (2005). Socio-economic barriers to learning in contemporary society. In E. Landsberg, D. Kruger \& N. Nel (eds.), Addressing barriers to learning: A South African perspective. Pretoria: Van Schaik.

Ramnarain, U., \& Schuster, D. (2014). The pedagogical orientations of South African physical sciences teachers towards inquiry or direct instructional approaches. Research in Science Education, 44(4), 627-650. https:/ / doi.org/10.1007/s11165-013-9395-5

Richardson, V. (1996). The role of attitudes and beliefs in learning to teach. In J. Sikula (ed.), Handbook of research on teacher education (pp. 102-119). New York, NY: Simon \& Schuster Macmillan.

Saldana, J. (2009). The coding manual for qualitative researchers. London: SAGE.

Sarrason, S. B. (1996). Revisiting "The culture of the school and the problem of change." New York: Teachers College Press.

Savinainen, A., \& Scott, P. (2002). The force concept inventory: A tool for monitoring student learning. Physics Education, 37(1), 45-52. https://doi.org/10.1088/0031-9120/37/1/306

Sawada, D., Piburn, M., Falconer, K., Turley, J., Benford, R., \& Bloom, I. (2000). Arizona collaborative for excellence in the preparation of teachers. Technical Report No. IN00. Phoenix: Arizona State University.

Smith, L. K. (2005). The impact of early life history on teachers' beliefs: In-school and out-of school experiences as learners and knowers of science. Teachers and Teaching: Theory and Practice, 11, 5-36. https:/ / doi.org/10.1080/1354060042000337075

Smith, L. K., \& Southerland, S. A. (2007). Reforming practice or modifying reforms? Elementary teachers' response to the tools of reform. Journal of Research in Science Teaching, 31, 45-77. https://doi.org/10.3102/0091732X07300046045

Suh, Y. (2005). Pedagogical content knowledge development in teaching science: A case of an elementary school teacher in an urban classroom. Columbia, NY: Columbia University Press.

Thomas, J. A., \& Pedersen, J. E. (2003). Reforming elementary teacher preparation: What about extant teaching beliefs? School Science and Mathematics, 103, 319-330. https:// doi.org/10.1111/j.1949-8594.2003.tb18209.x

Trigwell, K., Prosser, M., \& Taylor, P. (1994). Qualitative differences in approaches to teaching first-year university science. Higher Education, 27, 75-84. https:/ / doi.org/10.1007/BF01383761 
Upadhyay, R. B. (2005). Using students' lived experiences in an urban science classroom: An elementary school teacher's thinking. Wiley InterScience (www.interscience.wiley.com). https:/ / doi.org/10.1002/sce.20095

Weinstein, C. S. (1989). Teacher education students' preconceptions of teaching. Journal of Teacher Education, 40(2), 53-60. https:// doi.org/10.1177/002248718904000210

Wellington, J., \& Osborne, J. (2001). Language and literacy in science education. Philadelphia, PA: Open University Press.

Windschitl, M. (2002). Framing constructivism in practice as the negotiation of dilemmas: An analysis of the conceptual, pedagogical, cultural, and political challenges facing teachers. Review of Educational Research, 72(2), 131-175. https:/ / doi.org/10.3102/00346543072002131

Wubbels, T. (1992). Taking account of student teachers' preconceptions. Teaching and Teacher Education, 8, 137-149. https:/ / doi.org/10.1016/0742-051X(92)90004-M

Yin, R. K. (2003). Case study research: Design and methods. Thousand Oaks, California: Sage Publications.

\section{http://www.ejmste.com}

